\title{
State investments and human rights? The case of the Norwegian Government Pension Fund Global
}

DOI:

10.1108/AAAJ-01-2017-2830

\section{Document Version}

Accepted author manuscript

Link to publication record in Manchester Research Explorer

\section{Citation for published version (APA):}

Kreander, N., \& Mcphail, K. (2019). State investments and human rights? The case of the Norwegian Government Pension Fund Global. Accounting, Auditing \& Accountability Journal, 32(6), 1742-1770.

https://doi.org/10.1108/AAAJ-01-2017-2830

\section{Published in:}

Accounting, Auditing \& Accountability Journal

\section{Citing this paper}

Please note that where the full-text provided on Manchester Research Explorer is the Author Accepted Manuscript or Proof version this may differ from the final Published version. If citing, it is advised that you check and use the publisher's definitive version.

\section{General rights}

Copyright and moral rights for the publications made accessible in the Research Explorer are retained by the authors and/or other copyright owners and it is a condition of accessing publications that users recognise and abide by the legal requirements associated with these rights.

\section{Takedown policy}

If you believe that this document breaches copyright please refer to the University of Manchester's Takedown Procedures [http://man.ac.uk/04Y6Bo] or contact uml.scholarlycommunications@manchester.ac.uk providing relevant details, so we can investigate your claim.

\section{OPEN ACCESS}




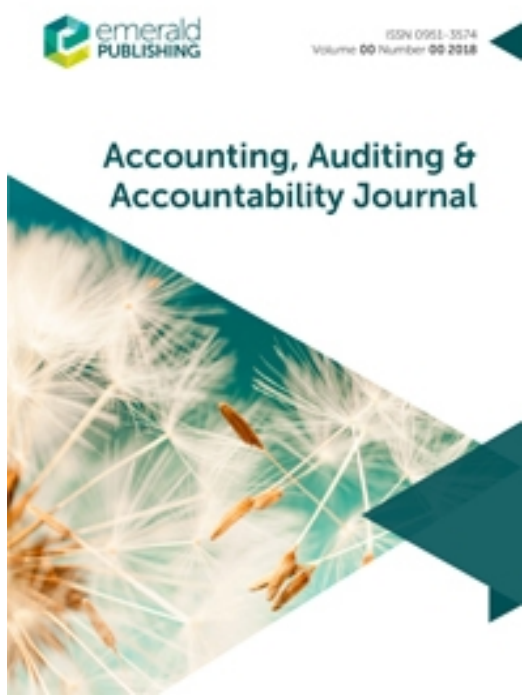

\section{State investments and human rights? The case of the Norwegian Government Pension Fund Global}

\begin{tabular}{|r|l|}
\hline Journal: & Accounting, Auditing \& Accountability Journal \\
\hline Manuscript ID & AAAJ-01-2017-2830.R3 \\
\hline Manuscript Type: & Research Paper \\
\hline Keywords: & $\begin{array}{l}\text { Human rights, Accountability, Sovereign wealth fund, Institutional } \\
\text { theory, Responsible investment }\end{array}$ \\
\hline \multicolumn{2}{|l}{} \\
\hline
\end{tabular}

\section{SCHOLARONE ${ }^{m}$ \\ Manuscripts}




\title{
State investments and human rights? The case of the Norwegian Government Pension Fund Global
}

\begin{abstract}
Purpose - The paper explores how the Norwegian Government incorporated its responsibility for human rights into the investment practices of its Global Pension Fund and how human rights issues were negotiated when exclusion was considered.
\end{abstract}

Design/Methodology/approach - Drawing on a series of interviews we analyse the way in which responsibility for human rights has been translated into the practices of the Norwegian Government Pension Fund Global.

Findings - The paper documents how a large investment fund used several mechanisms to address human rights risks. We demonstrate that different logics among actors sometimes impeded addressing human rights issues. Our findings demonstrate that sovereign wealth funds can be held accountable for human rights.

Research limitations/implications - The paper illustrates the difficulty of co-operation between actors with different logics. This can result in institutional conflict, but also in positive outcomes for human rights.

Practical implications - Attempts to introduce human rights into state investments may result in increased insitutional complexity. Our findings indicate that state investors can address human rights issues, but that the ability to do so is diminished where divestment creates political tension.

Social implications - Large investors can influence companies on specific human rights issues.

Originality/value - This is one of the first empirical investigations of the human rights practices of a sovereign wealth fund. We contribute to the literatures on accounting and human rights, sovereign wealth funds and institutional theory.

Keywords Human rights, Sovereign wealth fund, Institutional theory, Responsible investment, Accountability

Paper type Research paper 


\section{Introduction}

Forced relocations, slavery, violence and other human rights violations are problems connected to business operations today (Crane, 2013; Council on Ethics, 2014; McCorquodale and Simons, 2007). It is contested to what extent investors have responsibility for human rights violations linked to companies in their portfolios (Mestad, 2011). This question is especially acute for state based investors, since states have a duty to uphold human rights (Human Rights Council, 2011). The Norwegian Government Pension Fund Global (hereafter GPFG) has been accused of investing in firms which seriously violate human rights (Alm, 2013; Hemstad, 2012; Rainforest Foundation, 2012). The GPFG is the largest Sovereign Wealth Fund (hereafter SWF) in the world (Braunstein, 2017) and the first SWF that attempted to incorporate human rights into its investment process.

In 2001, the Norwegian government commissioned a Green Paper which outlined how the states human rights obligations could be integrated into the GPFG (NOU, 2003). The Green Paper was developed by a group of experts and refers to the states obligations as outlined in the International Covenant on Civil and Political Rights and the International Covenant on Economic, Social and Cultural Rights. The subsequent legislation resulted in the establishment of a Council on Ethics in 2004/5 tasked with ensuring that companies are excluded from investment where there is an unacceptable risk of contributing to: "serious or systematic human rights violations, such as murder, torture, depravation of liberty, forced labour, the worst forms of child labour and other forms of child exploitation" (Council on Ethics, 2008). The GPFG thus became one of few SWFs that consider human rights issues (Council on Ethics, 2013; NBIM, 2008). ${ }^{1}$ The introduction of the Council changed the institutional architecture of the GPFG and means that three organizations are involved in ensuring that the GPFG meets both its ethical and financial obligations: the Ministry of Finance (owner of the GPFG), the Council on Ethics for the GPFG, and the asset management arm of the Bank of Norway (NBIM). The attempt to hold GPFG to account for human rights obligations resulted in a new organization that adds complexity to the GPFG and creates the potential for conflicting accountabilities (Bovens, 2010; Gregory and Hicks, 1999; McKernan and McPhail, 2012).

These changes to the GPFG reflect significant shifts in understanding of the human rights responsibilities of both states and businesses generally. In a parallel development, the United Nations adopted a set of Guiding Principles on Business and Human Rights (the UNGP's) in 2011. The endorsement of the UNGP's was significant for two reasons: first, they require business to take responsibility ${ }^{2}$ for human rights, and second, they clarify that the human rights responsibilities of nation states apply to all state activities, including its dealings with business. In 2016, NBIM, published a human rights document that draws on the UNGP's (NBIM, 2016). The UNGP's provided clarity on the logic of incorporating human rights into the practices of the GFPG. While a growing body of literature has explored the implications of the UNGP's

\footnotetext{
${ }^{1}$ The only other SWF we know addresses human rights is the New Zealand Superannuation Fund.

${ }^{2}$ We use the language of human rights to refer to state responsibility for human rights in this paper. The intention is not to conflate the accountability of the state and its responsibilities (Bovens, 2010; Gregory and Hicks, 1999). Rather, the paper is based on the accounting literature that outlines the multifaceted and contested nature of the relationship between accountability and responsibility (Kamuf, 2007; McKernan, 2012). We contend that while responsibility is a 'container word', imbued with political, moral, and legal meaning, accountability can be related more to the institutional arrangements by which accounts are given and received (Bovens, 1998).
} 
for business, there are few studies of how states have translated their responsibility for human rights into their dealings with business or whether this results in changes to practices and institutions. We know little about how it is impacting notions and practices of accountability.

Drawing on institutional theory (Lounsbury, 2008; Greenwood et al., 2008) this paper explores the implementation of the Green Paper, the establishment of the Council on Ethics and subsequent recommendations to exclude firms from the GPFG for human rights violations. The Council on Ethics operates as a new institutional accountability mechanism. We explore this organizational innovation by the state (Jay, 2013) to address a complex problem: ensuring the states responsibility to protect human rights is not contravened by the investments it makes through its SWF (Greenwood et al., 2011). Through interviews with individuals in key institutions, this paper explores two research questions. First, how did the Norwegian Government incorporate its responsibility for human rights into the investment practices of its Global Pension Fund? Second, how were human rights issues negotiated when exclusion was considered. The literature suggests that, organizations can engage in different kinds of positive and negative responses in the face of organizational complexity (Oliver, 1991; Pache and Santos, 2010). We study the strategies adopted in the face of multiple accountability frameworks that result from the introduction of a new entity designed to help establish new responsibilities within an established institutional field.

Despite its size, the GPFG has received little academic scrutiny (Reiche, 2010). ${ }^{3}$ More broadly, there is little academic literature in accounting and finance on how human rights ${ }^{4}$ impacts on investments. This paper makes three contributions to the literature. First, we respond to McPhail et al's (2016) call for more accounting studies of the emerging business and human rights agenda by providing one of the first studies of how a state has attempted to introduce human rights into its investment practices. Second, the paper contributes to the institutional theory and multiple accountability literatures (O'Dwyer and Boomsma, 2015). In particular, we respond to Greenwood et al's (2011) call for more research on the complexity that confronts organizations as a result of having to deal with multiple logics. We define logics as the jointly held, taken-for-granted values and beliefs of those within the field (Reay and Hinings, 2009). Greenwood et al., (2011) conclude that, "the last decade has seen greater interest in understanding how multiple logics - albeit, still rarely more than two-play out within organizational fields" (Binder, 2007; Johed and Catasus, 2015; Pache and Santos, 2010; Reay and Hinings, 2009). This paper responds by studying the interplay between three logics: the financial logic in the Bank of Norway/NBIM, the human rights logic of the Council on Ethics and the political logic of the Ministry of Finance. Third, we contribute to the literature on SWFs and in particular to the understanding of the broader purposes that SWF's could serve (Dewenter et al., 2010; Mehrpoya, 2015; Midtun et al., 2013).

The paper is structured as follows. The following section reviews literature(s) on accounting for human rights, SWFs and institutional theory in order to locate our study and its contribution to the literature. We outline the methods adopted in section 3. Findings are discussed in section 4. The final section provides concluding thoughts.

\footnotetext{
${ }^{3}$ The academic research on the GPFG has a different focus, for example, Reiche (2010) focused on climate change.

${ }^{4}$ But see the 2011 Special Issue of Critical Perspectives on Accounting (No.8) and AAAJ (No. 4) in 2016.
} 


\section{Human rights, accounting and institutional theory}

\subsection{Accounting, accountability and human rights}

The International Covenant on Civil and Political Rights and the International Covenant on Economic, Social and Cultural Rights outline the states duty, to respect (in the sense of not infringing) individual human rights and their obligation to fulfill these rights.

However, human rights scholars have become concerned that this rights framework is not reflected in Governments relationships with the private sector and is also not reflected in the role that corporations can play in both the protection and violation of human rights (McCorquodale and Simons, 2007).

In recognition of the growing impact of corporations on human rights, the United Nations Human Rights Council endorsed the "Guiding Principles on Business and Human Rights" (hereafter the UNGP) in 2011 (Human Rights Council, 2011). The UNGP's re-focus attention on obligations for nation states that exist under international law on all their activities and provide the first authoritative reference point for corporations' human rights responsibilities. They are based on three core principles. First, the state duty to protect against human rights abuses in all its activities, including its relationship with business. Second, business' responsibility to respect human rights. Third, the need for more effective remedies for victims of human rights abuses (Human Rights Council, 2011). While the UNGP's place an obligation on states to encourage businesses within their jurisdiction to respect human rights, they also underline that the human rights obligations of government apply to all state dealings with business and therefore to the investments which states hold through SWFs. This shift in thinking represents a respecification of what the state and corporations are answerable for and potentially impacts the institutional arragments through which institutions are held accountable.

The Norwegian Ministry for Foreign Affairs is supportive of the UNGP's (St.Meld. 10, 2009). In 2013 the Norwegian government passed legislation that requires large corporations to disclose how they integrate social responsibility into their strategies, including any policies, principles, procedure and standards that are followed (Lovvedtak 44, 2012-2013). The Norwegian Ministry of Foreign Affairs stipulates that "respecting human rights; upholding core labour standards and ensuring decent working conditions;" are key aspects of corporate social responsibility (St.Meld. 10, 2009). Indeed, some claim that establishing an ethical investment policy for the GPFG was the most important corporate social responsibility policy of the the Norwegian government (Midttun et al., 2013). Within Norway, the emergence of human rights in finance is connected with the institutional legitimacy of the GPFG (Suchman, 1995). For example, the Strategy Council ${ }^{5}$ for the GPFG have noted the importance of the investments being seen as 'legitimate' by the people of Norway (Strategy Council, 2013). The ethical investment policy of the GPFG, along with requiring investee companies to adhere to frameworks such as the OECD Guidelines provides legitimacy for NBIM's investment activities (NBIM, 2008; Clegg, 2010). NBIM, signed an investor declaration supporting the UNGP's in 2011. The Ministry of Foreign Affairs also launched a National Plan for implementing the UNGP's (Ministry of Foreign Affairs, 2015). On the surface at least, these policy developments represents an attempt by the Norwegian government to implement its human rights responsibilities, across government functions, including its SWF (Human Rights Council, 2011; Meld.St. 10 2014-2015).

There is a growing body of research investigating this business and human rights agenda (Seppälä, 2009; MacDonald, 2011). Initial studies focused on the extent to which human rights can operate as potentially enforceable norms of conduct for corporations (Campbell, 2006). The emerging business and human rights field has been welcomed as a new framework for exploring the function of the accounting

\footnotetext{
${ }^{5}$ The Strategy Council is a group of investment experts advising the Ministry of Finance about investment matters relating to the GPFG.
} 
discipline within society (Gallhofer et al., 2011; Wettstein 2012). Li and McKernan (2016) explore the potential for human rights as an accountability construct. Muchlinski (2012) suggests that the result of an evolving understanding of the human rights duties in corporate law might challenge the established shareholder self interest models and move us towards a new understanding of the role of business in society. Others have questioned whether attempts to incorporate human rights into regulatory developments have resulted in substantive improvements in working conditions (Islam and McPhail, 2011). Indeed, some suggest that the imposition of human rights codes has resulted in reduced income and job security for workers (Sinkovics et al., 2016).

A key discussion within the literature has been the extent of corporate responsibility for human rights. Wettstein (2012), explores the conditions under which corporations might also have a positive obligation to protect victims of human rights violations. By contrast McPhail and Adams (2016) study how notions of corporate accountability for rights are discursively emerging in practice.

There is a small body of work that is focused on the business-state nexus in relation to human rights responsibilities. Cooper et al., (2011) have explored the extent to which government health and safety accounting systems set up with the aim of protecting rights can work against those whose rights they are intended to protect. Drawing on the case of the Chad-Cameroon oil pipeline, Sikka (2011) contended that, stabilization clauses were used to constrain the ability of developing countries to protect human rights. Focusing on the state, Siddique and Uddin (2016) draw on Cohen's work on States of Denial to explore how the Bangladesh government sought to avoid accountability for human rights in relation to the Rana Plaza disaster. There is also interest in whether responsibility for rights could be extended to inter-governmental organizations like the IASB and the World Bank (McPhail et al., 2016).

While this brief review of the literature indicates a growing interest in accountability for human rights, there is little analysis of how the UNGP's re-specification of the human rights responsibilities of the state are impacting institutional arrangements. We know little about how these responsibilities take on a form of accountability (Bovens, 1998; 2010). The Norwegian Government's incorporation of the UNGP's into the investment practices of the GPFG provides one example of this.

\subsection{Sovereign wealth funds}

The GPFG is the largest SWF in the world (Braunstein, 2017). The size of this fund was 7510 billion NOK or $\$ 871,2$ billion in December 2016 (NBIM, 2016b). SWFs manage investment portfolios on behalf of governments that own the portfolios (Dewenter et al., 2010). SWFs are significantly larger than hedge funds and private equity funds (Mehrpoya, 2015). SWF assets reached $\$ 7,4$ trillion at end of 2016 (www.swfinstitute.com). Many of the largest funds in the world are SWFs (www.swfinstitute.org). The objectives and behavior of SWFs are not well understood (Kotter and Lel, 2011) and their size, combined with growth and government links has fuelled concerns about how they are used (Truman, 2010). One such concern is that SWFs could be used to pursue political and social ends in addition to financial goals (Braunstein, 2017; Kotter and Lel, 2011). For example, Knill et al., (2012) found that political motives influence SWF investments. It has also been shown that SWFs can influence companies they invest in (Dewenter et al., 2010). There has been cases when SWFs have influenced government actions (Dewenter et al., 2010). However, the research on SWF's has thus far not engaged the field of business and human rights. There is little research on how the state's human rights obligations is integrated into SWFs or how SWFs could be held accountable for human rights

Much of this discourse about SWF activity is negative, in the sense that there have been concerns that foreign governments via SWFs could take control over assets such as ports, defence companies and telecommunication (Mehrpoya, 2015; Truman, 2010) or demand more positive policies towards the SWF host nation (Dewenter et al., 2010). In contrast we explore a different possibility, that is, whether the social objectives of SWFs could play a positive role (Clark and Hebb, 2004; Midttun et al., 2013) by promoting respect for human rights?

\subsection{Institutions, Logics and Complexity}


As outlined above, partly in response to the UNGP's, new forms of state and business responsibility for human rights is becoming institutionalised. Specifically, older human rights frameworks are being translated into a form which affirms the responsibilities of states when dealing with and investing in business (Human Rights Council, 2011). This in turn is resulting in new institutional logics of accountability (Ezzamel et al., 2007). We apply institutional theory to the study of SWF accountability for human rights issues by studying how the mature field of SWFs ${ }^{6}$ impacts, and is impacted by, the emergence of human rights as a new issue for that field (O'Sullivan and O'Dwyer, 2015).

From an institutional theory perspective, logics, fields and change are all interconnected (Reay and Hinings, 2009). Logics frame decision making, shaping action within the field and creating a common sense of purpose (Friedland and Alford, 1991; Thornton and Ocasio, 2008). While the literature recognises that two or more institutional logics may exist simultaneously (Scott, 2008; Thornton and Ocasio, 1999) it never-the-less suggests that a single belief system and related practices will dominate (Scott, 2008; Thornton and Ocasio, 1999). The Norwegien Governments' Green Paper attempted to introduce human rights alongside the financial requirements of the fund. This resembles the situation in hybrid organisations, which draw on more than one logic (Battilana and Dorado, 2010; Jay, 2013).

The logic of the UNGP's is beginning to impact institutionalized forms of accountability at the state level. The Green Paper and the establishment of The Council on Ethics, represents an organizational innovation (NOU, 2003; Jay, 2013) to ensure the Norwegian governments' responsibility to protect human rights is not contravened by the investments it makes through its SWF (Greenwood et al., 2011). Through the Council on Ethics, a new human rights logic was introduced into the state investment process, which represented a challenge to how the SWF managers pursued their goals (Pache and Santos, 2010). According to institutional theory the introduction of the Council on Ethics represents a challenge to the way organizational participants make sense of what they do and introduces a tension between social and commercial expectations (Meyer and Rowan, 1977; Pache and Santos, 2013).

We start with the assumption that introducing responsibility for human rights into the GPFG adds complexity. To the extent that this new logic is different from the established logic this creates challenges and tensions for organizations that are exposed to them (Greenwood et al., 2011). As Greenwood et al., (2011) comment, "Organizations face institutional complexity whenever they confront incompatible prescriptions from multiple institutional logics." We aim to understand how the organisations responsible for the GPFG experience and respond to this complexity. We are interested in how the state institutions respond to the responsibilities outlined in the Green Paper (Kraatz and Block, 2008; NOU, 2003).

The institutional theory literature suggests that the relationship between multiple logics is complex. For example, sometimes there is resistance to and oscillation between logics, at other times there is synthesis, while other studies indicate that combining logics can result in innovation (O'Mahony and Bechky, 2008; Jay 2013). As Jay (2013) explains, multiple logics "can create important sites of innovation" as organisations attempt to navigate paradox (Reay and Hinings, 2009; Stark, 2009) and the emergence of new practices and institutions (O'Mahony and Bechky, 2008). This is because combining logics means bringing together novel combinations of capital, tacit knowledge, and regimes of justification - means and ends - resulting in what Stark (2009) called the "sense of dissonance." However, other studies suggest that combining logics can lead to organizational instability and field changes that are characterized by power struggles (Fligstein, 1987; Thornton and Ocasio, 1999; Zilber, 2002). The

\footnotetext{
${ }^{6} \mathrm{We}$ consider the SWF field to be mature in terms of its age. SWFs date back to 1854 when the Texas Permanent School Fund was incepted (www.swfinstitute.com). The Saudi SAMA fund was established in 1952 (Truman, 2010).
} 
literature suggests that organizations engage in compromise, avoidance, defiance, or manipulation when faced with competing external demands (Oliver, 1991; Pache and Santos, 2010).

\section{Method}

We study the GPFG, which being the largest SWF and first to address human rights is an extreme case that can generate unique insights (Patton, 2002; Parker and Northcott, 2016). We adopted case study methods in order to answer our research questions (Lukka, 2014: Parker and Northcott, 2016). ${ }^{7} \mathrm{We}$ conducted fifteen interviews by 2016. Our choice of method aligns with calls for more interview based research in institutional theory (Suddaby, 2010). We identified interviewees best placed to inform our inquiry, based on an initial analysis of the GPFG (Parker and Northcott, 2016, see Figure 1). We interviewed key individuals across the organizations responsible for incorporating human rights into the GPFG's investments. These interviewees included members of the Council on Ethics and former staff from the Ministry of Finance with responsibility for the GPFG. We interviewed a former NBIM analyst and a former member of the Environmental, Social and Governance (hereafter ESG) issues team at NBIM. ${ }^{8}$ In addition we interviewed members from the OECD Contact Point in Norway who evaluated whether NBIM adhered to the OECD Guidelines for Multinational Enterprises (OECD, 2011). We also interviewed some non governmental organizations (eg Amnesty, Forum ${ }^{9}$, and Rainforest Foundation), which have engaged with NBIM on human rights (NBIM, 2013b). The OECD and NGO interviews were based on snowball sampling (Patton, 2002). For example, Stohl and Stohl, (2010) document the key role human rights NGOs have had in shaping the human rights field and Lounsbury (2008) notes how social movement activists can establish a new practice field. A list of interviewees is provided in Table 1 below. The semi-structured interviews took place in Oslo, Stockholm and Buxton (UK) in 2014 to $2016^{10}$ and lasted about one hour. The interviews were recorded and fully transcribed. ${ }^{11}$ In addition, notes were taken at each interview and written up after the interview. The interviewees from the Council on Ethics and the Ministry of Finance and NBIM all had several years of experience with responsible investments. We interviewed three individuals from the Council on Ethics to cover the entire time-period it has existed. This was also done to validate the findings by checking if answers to the same questions were aligned between the interviewees (Brinkmann and Kvale, 2015). We also checked some statements by interviewees by asking another interviewee what they thought about the same issue. Three of our interviewees were in the group producing the Green Paper that was the foundation for the ethical investment policy for the GPFG (NOU, 2003).

Following Eisenhardt's (1989) advice to include different groups, we have interviewed various stakeholders to get expert views on how human rights have been integrated into GPFG investments. In addition, we attended investment conferences where Council on Ethics and NBIM staff presented and we had informal discussions with some current members of the Council on Ethics and NBIM which informed our research. In our method we assume that Actors, "represent" and give voice to institutional logics (Pache and Santos, 2010).

In the interviews we asked how the GPFG deals with human rights issues in developing countries, what the view of the UNGPs applicability for the GPFG is, how the GPFG monitors companies globally, what companies the GPFG has examined for human rights violations, how the GPFG engages with firms on human rights issues, how the Council on Ethics, the Ministry and NBIM co-operate, accountability

\footnotetext{
${ }^{7}$ A case study based approach has proved fruitful for study of large funds (Reiche, 2010).

${ }^{8}$ We also had informal discussions with a former NBIM financial analyst in 2014.

${ }^{9}$ Forum is an NGO involved with human rights.
}

${ }^{10}$ Other papers have similar periods for field work. Binder (2007) collected interviews over three years. O'Sullivan and O'Dwyer (2015) had interviews over 30 months.

${ }^{11} \mathrm{We}$ did not record the interview with the former NBIM analyst due to confidentiality concerns. The interview with the Council on Ethics in 2015 was not recorded. 
related to the GPFG and some specific questions tailored to each interview. These qustions drew on annual reports, reports, websites and other sources from the organizations which we studied in advance.

All interviews were manually coded using a coding system constructed around our aims and research questions (Brinkman and Kvale, 2015). The main codes for the first research question were: Human Rights, Accountability, Engagement, Consequences, Motivation and Institutional Theory. The main codes for the second research question were: Internal negotiations, External negotiations, Power struggle and Other issues. The interview transcripts were cross-checked against the initial recordings to rectify any mistakes. Answers to questions were cross-checked between interviews. The researchers both coded one interview. A high rate of consistency was achieved (70\%) and all differences were discussed and amendments were made. Interviews were then coded into Nvivo for further analysis. The choice of examples from our data was driven by our theoretical focus (Lukka, 2014).

We used annual reports and other material from the Council on Ethics and NBIM to cross check interview findings. Newspaper articles from media and the websites of the organisations mentioned above were used to triangulate findings (Patton, 2002). For example, annual reports from the Council on Ethics that cover the cases in Table 2. We studied reports from NBIM (NBIM, 2013; 2014b; 2015; $2015 \mathrm{~b}$; 2016b) and the NBIM document on children's rights. We used reports from the Ministry of Finance regarding management of the GPFG (Meld.St.21 2014-2015) ${ }^{12}$. Regarding how the Council operates and rationale for the human rights criterion we cross checked with the Green Paper (NOU, 2003 and Nystuen, 2011). In terms of co-operation within the GPFG and the SRI approach we have studied the Strategy Council (2013).

\section{INSERT TABLE 1 HERE}

We acknowledge that the GPFG is not a typical SWF when it comes to human rights. Most SWFs do not consider human rights issues in their investments. This means the findings cannot be generalised to all SWFs. Nevertheless we think there can be lessons on managing multiple logics which other investors can benefit from, a measure of theoretical generalisability (Parker and Northcott, 2016). We discuss our findings in the following section.

\section{Findings}

In this section we explore the institutionalisation of human rights responsibilities outlined in the Green Paper into the GPFG and the resulting complexity. The discussion is structured around our research questions. First, we explore how the Norwegian Government incorporates its responsibility for human rights into the investment practices of the GPFG. Second, we explore how human rights issues are negotiated when exclusion is considered. We draw on the institutional literature to make sense of how the recommendations are enacted (Greenwood et al., 2011).

\subsection{How did the Norwegian Government incorporate human rights into the GPFG?}

We begin with a brief background of the GPFG. Thereafter we explain the new institutional architecture that resulted form the Green Paper, focusing on the fund manager NBIM and the Council on Ethics. By investigating how the ethical policy and the Council on Ethics was introduced into the investment process, we explore how an abstract notion like human rights takes on tangible qualities in the form of practices that exert influence (McPherson and Sauder, 2013).

\footnotetext{
12 We have looked at other reports also, as well as other Council on Ethics reports, but due to space constraints, have not referenced these.
} 
Norway's first oil field became operational in 1971. Up to 1990 the oil revenue was mainly used in the general budget, but in 1990 the Oilfund law was approved. NBIM was established and the first investments in shares occured in 1998 (See Appendix 1). The GPFG invests in countries outside of Norway. The Green Paper recommended including human rights in GPFG investment decisions (NOU, 2003). The reasoning behind the recommendation was first, that human rights are anchored in the Norwegian constitution and second that Norway has many international human rights obligations in law.

However, the motivation for the Green Paper needs to be contextualised in relation to the pressure placed on the Norwegian government via NGO's. NGOs helped to bring human rights issues to the fore by campaigning for an ethical policy for the GPFG (Forum Intervewee, Bay, 2002). SWF field actors resisted this pressure (OECD Contact Point interviewee). For example, the Norwegian NGO Future in our hands campaigned and issued a report which proposed ethical guidelines for the GPFG (Bay, 2002). This was followed by further NGO lobbying for an ethical investment policy for the GPFG in 2002 (Forum interviewee, Skredderberget, 2015). The ethical policy for the Fund was approved in 2004, following the Green Paper. This policy was revised in 2009. ${ }^{13}$ In 2016 the GPFG invested in 8985 companies and excluded 66 firms for ethical reasons (NBIM, 2016b).

\section{Institutional Architecture}

The institutional architecture that we describe below therefore reflects the multiple accountabilities of the Norwegian government: the fiduciary responsibility to ensure maximum returns on money invested in the fund but also the human rights obligations under international law.

The main institutional change proposed by the Green Paper was the establishment of a new entity, called the Council on Ethics, to monitor the new ethical policy. Figure 1 models the institutional architecture that was implemented after the Green Paper, from November 2004 until year end 2014. The Ministry of Finance owns the capital of the GPFG. The Ministry is accountable to the Parliament and decided on exclusions. Norges Bank via its Asset Management arm NBIM manages the investments of the GPFG.

The Council on Ethics represents a bridge between two mature fields, the fields of human rights and portfolio management. We contend that human rights is a mature field associated with mature professional interests. Greenwood et al., (2011) comment that the way competing logics impact on organizations depends on how logics are given voice, by whom and the resources at their disposal. The Green Paper determined that the Council on Ethics should be structurally differentiated, in that it was to sit outside the Bank and the Ministry. The Council represents both a fragmentation and formalization of demands (Greenwood et al., 2008). It represents an institutional voice for human rights, a formalization of demands, in the sense that it embodies the states human rights obligations. Formalization matters, according to Meyer et al. (1987), because the level of complexity confronting an organization is affected by the extent to which the organization is surrounded "by formally organized interests, sovereigns, and constituency groups, as opposed to environments made up of less formally organized groups, communities, or associations" (Meyer et al., 1987: 188). From Meyer et al's (1987) perspective, the introduction of the Council fragments the field, adding formality to a set of interests that results in increased complexity. Fund management becomes more complex when (a) human rights (logic) must be considered. Greenwood et al., (2011) contend that institutional complexity is shaped by the structure of the organizational fields within which they are located. The structure of these fields, create conflicting demands (Marquis and Lounsbury, 2007; Reay and Hinings, 2010).

\section{INSERT FIGURE 1 HERE}

The black arrows in Figure 1 refer to information flows between the organizations. This information sharing includes Annual reports, letters, meetings and web disclosures. The dotted arrows refer to the way in which the responsibility for human rights take on new accountability relationships. NBIM and

13 Before 2009 certain weapons were excluded. Other criteria included human rights violations, severe environmental damage, gross corruption and serious violations of ethical norms (Council on Ethics, 2008). 
the secretariat for the Council on Ethics meet regularly, for example five times in 2015, in addition to an annual meeting between the Ministry, NBIM and the Council on Ethics (NBIM, 2015b). The change in the organizational field results in new layers of accountability (Bovens, 1998). The Council on Ethics and NBIM are accountable to the Ministry and to Parliament. Next we elaborate on the Council on Ethics, then we discuss NBIM in more detail.

\section{The Council on Ethics.}

The Council on Ethics is an independent institution set up in 2004 as a result of the Green Paper. It monitors companies in the GPFG against a range of human rights issues and gives advice about exclusion of firms with the most serious violations (Meld.St. 21 2014/15). A key task for the Council is to ensure the state is accountable for the investments of the GPFG. The Council shares information about companies with NBIM and, up to 2015 made recommendations to the Ministry of Finance. ${ }^{14}$ After the recommendations have been processed by the Ministry and NBIM they are made public. NGOs share information about human rights violations with the Council and NBIM (CE interviewee 3, Rainforest Foundation interviewee). The Council on Ethics is an important institutional accountability mechanism (NOU, 2003). The interviewee from Amnesty characterised the Council as the "official watch dog" (of the GPFG). The Council seeks to be accountable by publishing reports about firms to be excluded as the following quote illustrates:

The reports from the Council are very legalistic...they are very thorough, very well argued. Ministry of Finance interviewee 1

The Council consists of five individuals with expertise in different areas such as the environment and human rights. A secretariat of eight researchers work for the Council on Ethics to ensure compliance with the ethical investment policy. The members of the Council have primarily a legal background. The composition of the Council is important, and will affect the potential for conflicting logics. One of the key assumptions within institutional theory is that professional actors will adhere to that group's primary logic (Friedland and Alford, 1991). The incorporation of human rights into the state investments therefore involves complexity, in part associated with the different professionals with potentially conflicting logics at the institutions (McPherson and Sauder, 2013). Others suggest a more complex and varied behavior by professionals as they employ logics in a creative way to manage competing tensions (Battilana and Dorado, 2010).

The Council on Ethics specified the following criteria for establishing corporate complicity in human rights violations (Nystuen, 2011). First, there must exist a clear and visible link between the company's operations and existing breaches of the guidelines. Second, the breaches must have been carried out with a view to serving the company's interests. Third, the company must either have contributed actively to the breaches, or had knowledge of the breaches, but without seeking to prevenent them. Finally, the norm breaches must either be ongoing, or there must exist an unacceptable risk that norm breaches will occur in the future. Earlier norm breaches might indicate future patterns of conduct.

An important aspect of the Council's work on human rights is that companies will only be recommended for exclusion if the violations are ongoing and/or there is a significant risk of contributing to future violations (Nystuen, 2011). This means that serious past human rights violations by a corporation doesn't lead to exclusion. This is why, the Council withdrew its recommendations to exclude Daewoo, Oil and Gas Corporation, GAIL India, Korea Gas and POSCO (Council on Ethics, 2013). ${ }^{15}$

\footnotetext{
${ }^{14}$ There was a change in regime in 2015 , after that on the decision to exclude companies was moved to the Board of the Bank of Norway. This reform was implemented to make the process less political (Strategy Council, 2013). We focus on exclusions recommended based on human rights from 2005 to 2014.

${ }^{15}$ The concern was human rights violations in conjunction with the construction of a pipeline. After the pipeline was completed the case was withdrawn.
} 
In addition to establishing the Council, the Green Paper introduced a new set of human rights obligations into the logic of the fund manager (NOU, 2003). The Green Paper introduced a challenge to NBIM's logic by requiring them to adopt "Strategies for ethical fund management" that were designed to consider human rights (NOU, 2003).

The strategy outlined in the Green Paper included three main elements: "exercising ownership" through engagement and voting on human rights issues; negative screening; and exclusions. The Green Paper states: "The fund can together with other investors, demand from companies that ... they put in place systems in order to ensure the company does not contribute to violations of basic human rights." Further, section 5.24 suggests that the sale of shares can be a consequence if NBIM's engagement does not produce results (NOU, 2003).

NBIM initially focused their human rights engagement with firms on children's rights (NBIM, 2008). This focus was motivated both on ethical grounds and by arguments that harming children's rights poses risks for both companies and the global economy (Kvam, 2008). NBIM's engagement in children's rights represented an attempt to translate the recommendations of the Green Paper and start with a manageable issue. NBIM produced a children's rights expectation document (Kvam, 2008; NBIM, 2008) which was actively communicated to companies in the portfolio (NBIM Interviewee 2). NBIM has evaluated compliance with their Expectations on Children's Rights (NBIM, 2010). In these reports, NBIM studied compliance among portfolio companies with their expectations in sectors such as agriculture, mining, steel and toys (NBIM, 2010). To an extent NBIM aimed to be accountable:

NBIM reports regularly about exercise of ownership. NBIM interviewee 1

However, this initial attempt to apply human rights was criticized for being relatively narrow (The Norwegian NCP, 2013). Some interviewees commented on this, for example:

Why have they chosen children's rights and not another type of rights? Why have they not chosen labour rights for example? It is not a broad range of rights, that is covered in the focus areas. OECD Contact Point member

Others concurred and stated that children's rights was a relatively easy issue. The Amnesty Interviewee commented, "...compared to many other human rights challenges. This is, I guess, one of the easiest to choose." Considering childrens' rights but not other human rights can be seen as an example of selective coupling in order to manage competing logics (Pache and Santos, 2013). Thus NBIM's initial response to the imposed accountability for human rights was to focus on accountability for children's rights (O’Dwyer and Boomsma, 2015).

NBIM interviewee 1 provided insight into why NBIM initially focused on children's rights. This was due to a lack of a systematic framework, combined with a lack of data. The Amnesty Interviewee also commented:

I don't think it is only a matter of raw will. I think it is also a matter of, that they actually find it challenging. How to operationalize this kind of duty. Amnesty Interviewee

Without an explicit framework, the requirement for the Fund to implement human rights remained ambiguous. Goodrick and Salancik (1996) suggest that there is greater discretion depending on the level of ambiguity associated with a particular logic. Greenwood et al., (2011) similarly imply that ambiguity can be used to alleviate tensions between competing logics. However, the NBIM interviewee mentioned that the endorsement of the 2011 UNGP's was a 'watershed' when it comes to addressing corporate human rights violations. Human rights issues had been addressed before 2011 but it was difficult to get 
data and hard to put human rights issues into a systematic framework. The interviewee explained that the UNGP helped NBIM to address human rights in a systematic manner and integrate them into the investment processes. Through codes such as OECD Guidelines for Multinational Enterprises and the UN Global Compact, the UNGPs are translated for practice. For example, CE interviewee 1 said about the UNGP: "We try to apply it... as you can see from several recommendations we use them as a guiding principle." Whilst the member of the Secretariat for the Council commented that "we use them extensively". The NBIM expectation document on human rights is based on the UNGP (NBIM, 2016).

The OECD Guidelines for Multinational Enterprises were also amended in 2011, human rights obligations were included, based on the UNGP. NBIM has endorsed the OECD Guidelines and expects companies in the portfolio to comply with them, indeed the OECD Principles and the Global Compact are mentioned as reference points in the mandate for NBIM (NBIM, 2014b). The NBIM Interviewee 2 also said that these standards are "a natural starting point for responsible fund management." In 2015 NBIM updated its children's rights document and integrated it with the UNGP (NBIM, 2015d). However, ten years after the requirement to integrate human rights was introduced the NBIM interviewee 1 said that "the work with investment and human rights is still in a development phase".

The new requirements in the Green Paper had to be integrated into the logic of the bank. The introduction of new logics instigates new requirements for sense making. Because logics and sense making are associated with action, there is a need to provide new scripts for acting. An executive from NBIM provided further insight into the practice and process that emerged, informing us that NBIM developed a database on the larger holdings in the GPFG portfolio that included human rights issues and that these issues were translated into the established logic of portfolio risk analysis. ${ }^{16}$

Human rights risks in our portfolio, this is integrated into our country and market risk view, we consider this at sector and company level within the context of the business. NBIM Executive, personal communication in 2014

The CEO of NBIM stated that this database included 4100 portfolio companies in 2014 (NBIM, 2014). He also mentioned that NBIM divested 65 firms following sectorial risk assessments of extractive industries and the palm oil sector. Kraatz and Block (2008) argue that organizational participants interpret, translate and transform logics. They are not passive in the way in which new logics are received. The NBIM quote above indicates how human rights begin to be translated by a mature actor.

NBIM risk analysis includes social issues for sectors such as mining (NBIM, 2014b). The social issues NBIM focuses on are child labour, health and safety and human capital (NBIM, 2015b). This analysis results in an $\mathrm{ESG}^{17}$ score for companies. Companies with very poor ESG scores risk divestment. However, in 2016 the social side of this score, which includes human rights, seemed to count for a small part of the total. ${ }^{18}$ In 2014 NBIM analysed 24 companies because of high human rights risk (NBIM, 2014b). In 2015 NBIM divested more than 10 firms for which human rights breaches were a contributing factor (NBIM, 2015b).

NBIM engages with firms on many issues including child labour and climate change (NBIM, 2013). This engagement can take different forms, from writing e-mails and letters to face to face meetings with company management at all levels. For example, NBIM had 2304 meetings with companies in the portfolio in 2013. Environmental and social issues were discussed at some of these meetings (NBIM, 2013). NBIM is in direct dialogue with 500 to 700 companies (CE interviewee 3). NBIM also engages

\footnotetext{
${ }^{16}$ This NBIM executive did not wish to be interviewed, but we had a discussion over the phone and he provided
} this information in an e-mail.

${ }^{17}$ ESG stands for Environment, Social and Governance.

${ }^{18}$ In one example the social side counted for $12 \%$. The weighting of the social factors can vary from firm to firm. Source: Presentation by NBIM in Oslo 9.12.2016. 
with industry associations, standard setters and regulators (NBIM Interviewee 1). NBIM voted its shares in the 9000 companies the GPFG owned in 2015 at annual general meetings (NBIM, 2015).

Yet, there is a tension between the established finance logic of NBIM and the requirement that it takes responsibility for human rights violations by companies it its portfolio. This resembles the tension between the bank and development logics in micro credit (Battilana and Dorado, 2010). The mandate of NBIM to earn returns for the fund within certain risk parameters poses challenges for considering human rights. NBIM interviewee 1 pointed out that:

If the Bank excludes companies for purely ethical reasons, they would not do their job. NBIM interviewee 1

Due to the dominance of the finance logic, only parts of the human rights frameworks were put into investment practice (Human Rights Council, 2011; The Norwegian NCP, 2013). A member of the Strategy Council commented:

Do they [NBIM] want to be sort of a world police on social issues? I don't think so. And I am not sure they should be. If it is a financial risk, they should be, if it is something else, it is difficult. They have their mandate, which is to make positive returns to their portfolio. Strategy Council interviewee

While all interviewees agreed that it was not the aim of the GPFG per se to promote human rights, the Council on Ethics nevertheless held companies accountable for human rights:

Our aim is not really to further human rights, it is to avoid investment in companies that contribute to gross violations of human rights. But when we point to companies that violate human rights, you could see that as furthering human rights, in that no company really wants to be pointed at... Member of the Secretariat, Council on Ethics

From an institutional complexity perspective, one would expect that the requirement for NBIM to implement a human rights policy would be translated into the Banks existing logic and in the process would loose some of its change potential. The Green Paper could of course have simply proposed the adoption of a human rights policy by NBIM, however it's the addition of the Council on Ethics that represents an organizational innovation and secures a voice for human rights. Both the mandates and the logics of the Council on Ethics and NBIM are different (Strategy Council, 2013). The Council focuses on human rights issues without considering the financial obligations, something NBIM cannot do (NBIM interviewees). The Council on Ethics has been dominated by a focus on rights and a 'lawyer logic' (CE interviewee 2, Council on Ethics, 2013). NBIM has been dominated by a focus on financial return and 'finance logic' (NBIM interviewee 1). This has resulted in conflicts between "economist and lawyer logic" (CE interviewee 2, Ministry of Finance interviewee 1).

This raises questions about the precise role of the Council of Ethics and whether its function is to create productive tension in the logics and mitigate against the human rights responsibility being absorbed into the NBIM logic. Drawing on Stark (2009) the function of the Council may be to maintain a "sense of dissonance," as an accountability mechanism.

There seems to be a significant difference in the approach to human rights between the Council on Ethics and NBIM. Up to 2013 at least, NBIM focused mostly on children's rights, while the Council on Ethics addressed a wider range of human rights including labour rights, the rights of original peoples and related issues such as forced relocations (Council on Ethics, 2013). The insititutional networks of which they are a part, are also different. The Council on Ethics has had direct contact with John Ruggie ${ }^{19}$ and other human rights scholars (CE Interviewee 1). Through these connections and active participation at international conferences, the Council has helped to develop the investment and human rights field

\footnotetext{
${ }^{19}$ The UN Special Advisor on Business and Human rights and co author of the UNGP.
} 
(O'Sullivan and O'Dwyer, 2015). This participation in the human rights field and holding companies to account for human rights violations may point to a felt accountability for human rights in the Council (O’Dwyer and Boomsma, 2015).

NBIM chose a more limited presence in the investment and human rights field (Amnesty interviewee, Ministry of Finance interviewee 1; The Norwegian NCP, 2013). The reason for this difference is that the organisations have different mandates and logics.

Some institutional researchers explain institutional change as movement from one dominant logic to another (Hoffman, 1999). According to Greenwood et al., (2011), past research that focused on multiple logics tended to view the introduction of a new logic as a jolt to the field that brings in a new dominant logic - effectively separating one stable period of beliefs from another. From this perspective, contradictions between logics tends to be viewed as transitional rather than part of ongoing complexity. However, more recent research highlight the co-existence of multiple logics over time (Reay and Hinings, 2010). While we see the introduction of human rights as a jolt to the established logic within NBIM, we do not suggest that the establishment of the ethical investment policy and the Council on Ethics are an attempt to replace one logic by another, rather the logic of rights is intended to co-exist with the logic of return. For example, Reay and Hinings, (2010), discuss the way in which the introduction of business like approaches to health, conflict with, yet also co-exist with, a logic of "medical professionalism." The question then is what strategies are reflected in the way in which recommended exclusions are dealt with. We explore different strategies adopted in order to cope with this complexity. The following section investigates this.

\subsection{How are human rights issues negotiated when exclusion is considered?}

This section addresses our second research question: how human rights issues are negotiated when exclusion is recommended. Table 2 summarises the recommendations for exclusion of companies from the GPFG based on human rights from 2005 to 2014. Through these recommendations the Council saught to hold NBIM accountable for its investments.

Our theoretical perspective leads us to suggest that the dynamics between different logics, partially explains the outcomes of the recommendations. The literature suggests that multiple logics can result in a range of outcomes including oscillation among logics, synthesis, dissonance, and innovation practices (Jay, 2013; O'Mahony and Bechky, 2008; Stark, 2009). Organizations can engage in compromise, avoidance, defiance, or manipulation when faced with competing demands (Oliver, 1991; Pache and Santos, 2010).

\section{INSERT TABLE 2 HERE}

By the end of 2014, The Council had recommended exclusion of thirteen companies due to human rights violations. In addition two firms were excluded partly for human rights reasons. Three of these firms have been excluded for human rights reasons. Vedanta Resources and Sesa Sterlite were excluded partly for human rights, but mainly for environmental reasons (Council on Ethics, 2013). In 2015 Daewoo and POSCO were excluded for environmental reasons. The Ministry did not exclude Monsanto, but approved a request by NBIM to engage with the company on child labour issues (NBIM interviewee 1).

We see different responses from the same institutions to the recommendations for exclusion. The Ministry of Finance responded in four different ways: first, accepting the human rights logic; second, alignment of logics leading to engagement and innovation; third, dissonance leading to rejecting the recommendation and fourth, dissonance leading to avoidance and conflict. We consider each of these responses in turn below and explore the reasons for the different reactions. 


\section{Human rights logic accepted}

We identified two cases where companies were excluded from the fund for human rights violations. The Council on Ethics recommended exclusion of Walmart and Wal-Mart de Mexico in 2005 due to violation of labour rights and children's rights. The recommendation was made public in 2006 when NBIM had divested its Walmart holdings. We think that the human rights logic may have been accepted in this instance as it was the first conduct based exclusion proposed and political ramifications may not have been fully anticipated. In addition, Walmart failed to respond to the Council on Ethics prior to the exclusion (Forum interviewee). ${ }^{20}$ The Indian seed company Zuari AgroChemicals was also excluded from GPFG in 2013 due to extensive use of child labour in dangerous work (Council on Ethics, 2013). Up to $30 \%$ of workers on farms connected to this company were children (Council on Ethics, 2013). Zuari is a comparatively small company and it may be that the Ministry of Finance forsaw little political complications arising from the decision.

Yet while the Ministry of Finance accepted the Council's recommendations, there is evidence that the Bank had not changed its finance logic (Braunstein, 2017). NBIM interviewee 1 said that:

Those exclusions have nothing to do with the Bank

Furthermore, the Council on Ethics interviewee 2 stated that the Bank was 'against exclusions'. In the above cases the Ministry accepted the Council logic and the Bank had to exclude. The GPFG exclusions also influenced the behavior of others in the field. One of the interviewees from the Council on Ethics commented that after this exclusion she received a phone call from a large Swedish pension fund (AP Fund 2) enquiring if the GPFG had been caught with any factual errors in the Walmart recommendation. Our interviewee said "No". Shortly after this fund excluded Walmart. The decision to sell spread through the investment community and resulted in others following (Council on Ethics, 2013), suggesting that the GPFG exerts an exo isomorphic influence within the investment field in Scandinavia (Souitaris et al., 2012; Kreander et al., 2015). ${ }^{21}$

\section{Alignment of logics leading to innovation \& engagement.}

In this section we consider an example where a recommended exclusion lead to innovation and engagement. As Jay (2013) explains, multiple logics "can create important sites of innovation" as organisations attempt to navigate paradox (Reay and Hinings, 2009). The hybrid seed industry in India is a case where NBIM attempted to improve the standards of agriculture through engagement with established companies. The Council on Ethics has been monitoring the hybrid seed industry in India since 2005 (Council on Ethics, 2008). The CE interviewee 1 mentioned that:

We look at the electronics industry in China, but also hybrid seed production in India, here we find something about working conditions which we include as part of human rights.

In 2006 the Council on Ethics recommended that the American agrochemical company Monsanto be excluded because of child labour in farms cultivating hybrid seeds connected to Monsanto in India (Council on Ethics, 2008). The Ministry of Finance did not exclude Monsanto but agreed that NBIM should engage with Monsanto on child labour issues. It would seem significant that part of the reasons for exclusion related to child labour, which may hint at alignment between logics. We know that NBIM has engaged with other sectors such as cocoa about children's rights (NBIM interviewee 2). Indeed, actors such as UNICEF have recognised the valuable work NBIM has done for children's rights (UNICEF, 2012). Engagement by NBIM was intended to be the main mechanism for translating human

\footnotetext{
${ }^{20}$ The Council sends a draft recommendation to the firm for comment before it issues the final recommendation. Companies have a chance to correct mistakes and defend themselves.

${ }^{21}$ In exo isomorphism the focus of alignment is external (Souitaris et al., 2012).
} 
rights responsibilities into practice (Former OECD Contact Point interviewee). Having a credible threat of exclusion and specific information is helpful for success in such engagement (CE interviewee 2).

This alignment lead to a measure of innovation and engagement. The NBIM interviewee 1 said that this engagement was an initiative from the Bank. The interviewee stated that NBIM had concluded that "we can do something about this". The CE interviewee 2 confirmed that engagement with Monsanto was a Bank initiative facilitated by information NBIM received from the Council on Ethics. NBIM came up with an engagement plan which convinced the Ministry of Finance. The plan included engagement with Bayer, another company in the sector (NBIM interviewee 2). The NBIM Interviewee 1 mentioned that this was rare because in most cases when the Council recommended exclusion, NBIM did not see a possibility to change corporate practice in a reasonable time. Here a change was possible, NBIM helped to improve corporate practice and retained the firm, a preferential solution for finance logic. While the Council achieved a solution to a human rights problem, which was acceptable for their ethics logic. This finding about NBIM is in line with research showing that institutional investors prefer dialogue as a means to enforce accountability (Uche et al., 2016).

Our NBIM interviewee 1 travelled several times to India and to Monsanto's headquarters in the USA as part of the NBIM engagement on children's rights. NBIM interviewee 2 also travelled to India to find out information directly. NBIM engagement was intended to improve corporate practice:

if you want to promote change to better practice in the companies, which is of course one of the reasons we did this... NBIM interviewee 2

This engagement led to less child labour in farms connected to Monsanto in India (Council on Ethics, 2013). More recent inspections showed a low incidence of child labour in Monsanto related farms in India (CE interviewee 3). This indicates that an alignment of logics helped the GPFG to enhance human rights practices in supply chains by reducing child labour. Indeed, two interviewees from the Council identified this case as a success. It provides an example of how SWFs can influence the firms they invest in and have a positive impact (Midttun et al., 2013).

This may be an example where innovation emerged out of alignment in logics (NBIM, 2008). Our NBIM interviewees said that NBIM had worked on sectorial initiatives to reduce child labour such as in the hybrid seed industry and the cocoa industry. NBIM has also worked with UNICEF to help improve children's rights (UNICEF, 2012). The development of more structured relationships between NGOs, UNICEF and NBIM may have contributed towards this sense that they "could do something about this" (Stohl and Stohl, 2010).

Dissonance leading to rejected recommendations.

However, there was some frustration in the Council on Ethics that it was difficult to get approval for excluding companies for human rights violations. Indeed, half of the companies recommended for exclusion for human rights were still in the GFPG portfolio in 2015 (See Table 2). NBIM also increased investment in them after they had been recommended for exclusion (Table 3 ).

Two issues emerge from our interviews that may explain some of the challenges associated with excluding companies for human rights violations. First, there is a perceived challenge of being able to evidence the violations. One interviewee commented,

But human rights is more challenging than the environment, because environmental degradation is more observable,

Member of the Secretariat for the Council on Ethics

Second, there is the challenge that the Council's recommendations are perceived as an assessment of 
states,

it is a frustration for us really, that we haven't excluded more companies on human rights... Very

often we end up with assessing states, which is not what we want to do. Because many human rights violations that are connected to our companies will be government driven. It is not the companies that prefer to do things in a wrong way, it is the governments.

Member of the Secretariat for Council on Ethics

Some of the difficulty in excluding firms for human rights violations therefore seems to be related to the concern that by excluding a company, the state of Norway is accusing another state of acting in an immoral way. As one interviewee put it:

Foreign state leaders might have an issue with an active engaging fund with views which are potentially controversial in the country. Strategy Council interviewee

The Council on Ethics has been clear that it is not part of their mandate to evaluate whether states violate human rights (Nystuen, 2011). However, this is difficult when large states such as China are involved. For example, the Council on Ethics recommended exclusion of PetroChina in 2010 due to documented human rights violations by its parent company China National Petroleum Corporation (hereafter CNPC) linked to construction of a pipeline through Myanmar (Council on Ethics, 2011). Such projects had been associated with forced relocation of villages, forced labour and killings (Council on Ethics, 2011). However, the Ministry of Finance rejected this recommendation in 2011, with the explanation that it was not clear that PetroChina was involved in the violations. The key point here was that the Ministry did not accept that PetroChina had responsibility for the activities of its parent company CNPC and another CNPC daughter company which was responsible for constructing the pipelines in Myanmar. A quote illustrates the reasoning behind this:

You can always hold parents responsible for the actions of the children, but you cannot hold the children responsible for the action of the parents. And it is the same in a governance structure or corporate structure so if something happens in a company, the parent company exercises control can be held accountable

Ministry of Finance, interviewee 1

Our interviewee from Amnesty disputed this interpretation and mentioned that complex organizational structures were used by many companies in order to avoid responsibility. However, this view was not accepted in the Ministry and the GPFG remains a shareholder of PetroChina. Human rights violations have also been linked to other oil pipeline projects (Sikka, 2011).

Some commentators believe that the Ministry's decision to retain PetroChina was linked to problems caused to Norway's relations with China after a Chinese activist was awarded the Nobel peace prize in 2010 (Alm, 2013). To quote Alm (2013) after this "China was suddenly closed to Norway". For example, Norwegian salmon exporters and Statoil have faced difficulties in China (Amland, 2011; Takla, 2011). ${ }^{22}$ Excluding PetroChina would therefore have been like "throwing gasoline on the flames" according to a former NBIM financial analyst. The NBIM interviewee 2 said that it does not make sense to the Chinese to claim that the GPFG excluding PetroChina "is not political". The PetroChina recommendation illustrates the difficulty of dealing with cases which have political consequences for a state's international relations and where a very large state is implicated in human rights violations. At the time Norway had a Foreign Minister who was keen on developing good relations with China. We extend the finding in Knill et al., (2012) that political motives can influence SWF investment with our finding that political motives also influence divestment decisions.

\footnotetext{
${ }^{22}$ After a Chinese activist got the Nobel prize Norwegian salmon exports to China fell by $70 \%$ (Amland, 2011). Statoil was excluded from negotiations about Chinese gas resources (Takla, 2011).
} 
Interviewee 2 from the Council on Ethics commented that other Ministries interfered with the process and blocked 'controversial' exclusions such as PetroChina. In this instance, a political logic allied with finance logic overrode the human rights logic of the Council ${ }^{23}$. The behavior of the Minstry of Finance is in line with findings in McPherson and Sauder (2013) who noted that "...the same actor may choose to employ different logics at different times depending on the immediate situation". This also fits with the "oscillation behavior" documented by Jay (2013) when multiple logics are present. There was a high level of complexity since several logics were involved (Greenwood et al., 2011).

However, even if it has been difficult to exclude companies for political reasons, one would imagine that a recommendation by the Council may result in no further shares being acquired by NBIM. As an objective measure of NBIM practice we studied GPFG shareholdings in companies which had been recommended for exclusion by the Council on Ethics for human rights violations. Nevertheless, these recommendations had not been accepted by the Ministry. We anticipated that if human rights risk were considered seriously by NBIM, the holdings in these companies would be stable (or decrease) over time. Table 3 presents the findings.

\section{INSERT TABLE 3 HERE}

Contrary to our expectations, the share the GPFG held in most of these companies increased from 2010 to 2014. For Korea Gas the increase in investment was fifteen times what we had expected. In the PetroChina case the increase was 332\% compared to an 109\% increase of the GPFG size. This shows that human rights risk did not affect investment or divestment decisions at NBIM in these cases. ${ }^{24}$ These findings are in line with those who are skeptical about human rights improvements (Islam and McPhail, 2011; Sinkovics et al., 2016).

\section{Dissonance leading to avoidance of accountability and institutional conflict}

Our final category is dissonance leading to avoidance and conflict (Oliver, 1991). The Council on Ethics recommended exclusion of Daewoo International, Korea Gas Corporation, Gail India and Oil and Natural Gas Corporation, in 2011 because of indirect participation in a controversial gas pipeline project in Myanmar. POSCO was added in 2012 after acquiring Daewoo. ${ }^{25}$ The Ministry never gave a reason why these companies were not excluded. It may be related to the PetroChina case, because the recommendation to exclude these firms was based on human rights violations in conjunction with a pipeline in Myanmar. The company responsible for operating and constructing this pipeline was CNPC, the parent company of PetroChina (Council on Ethics, 2013). If the companies above were excluded for human rights violations linked to the CNPC pipeline it would raise questions of why PetroChina was not excluded. The Council withdrew the recommendation to exclude these firms in 2013 judging that the risk for serious human rights violations was over after the pipeline was completed (Council on Ethics, 2013). The Ministry of Finance had the case for over two years without responding to it. ${ }^{26}$ There is a paradox here, Norway's Ministry of Foreign Affairs supported the development of the UNGP

\footnotetext{
${ }^{23}$ PetroChina was a challenge to NBIM, since excluding a major company causes tracking error for the portfolio.

${ }^{24}$ For two companies; Gail India and Posco we expected higher investment in 2014. However, this does not mean these firms were "underweighted", but rather that they had poor stock market performance. NBIM bought more shares in these firms as evidenced by the increased ownership share.

${ }^{25}$ POSCO owned $68 \%$ of the shares in Daewoo International at the end of 2012.

${ }^{26}$ The Ministry of Finance did request the Council to reassess the situation in Myanmar in 2012 given reforms in the country. The Council did so but upheld the exclusions (Council on Ethics, 2013).
} 
(St.Meld.10.2009; Jay, 2009). Yet the the Ministry of Finance hindered the implementation of the UNGP in the PetroChina case based on input from the Ministry of Foreign Affairs (CE Interviewee 2).

However, the Ministry's avoidance was not without consequences. Their behaviour, in part explained by the need to navigate multiple logics, resulted in increased tensions in the field. Three NGOs made complaints in 2012 to three OECD National Contact Points (hereafter NCP) related to POSCO. The Norwegian NGO Forum, lodged a complaint against NBIM at the Norwegian OECD NCP. The complaint was about potential human rights violations and environmental issues caused by a large new steelwork project in India by POSCO. Forum claimed that up to 20000 people would be displaced by this project. The OECD NCP in Norway examined this case and found that NBIM did not adhere to the OECD Guidelines for multinational enterprises which NBIM require investee firms to follow (Norwegian NCP, 2013). Specifically, NBIM did not co-operate with the NCP and the range of human rights NBIM addressed was too narrow (Norwegian NCP, 2013). This was widely reported in media in Norway. As a result NBIM and the Ministry of Finance started to attend OECD meetings and lobby for their view that the OECD Guidelines for multinational enterprises should not apply to GPFG (Forum interviewee, Curtis, 2014). Our NBIM 1 Interviewee explained the logic behind this:

PRI is for investors, the Global Compact is for companies. ${ }^{27}$

The CEO of NBIM also wrote a letter to the OECD investment Committee arguing the GPFG should be exempted from the OECD guidelines (NRK, 2013; OECD, 2014). A legal expert at the OECD NCP in Norway disputed this interpretation and argued that the OECD Guidelines apply to NBIM.

...NBIM as an investment fund engages in market activities in direct competition with other institutions and investors. Therefore they should be governed by the same rules. So it is no question for me that institutionally those Guidelines apply. That we can see as an additional argument for that they should have a human rights policy. OECD Contact Point in Norway, former member

The reaction of NBIM was similar to others who denied responsibility for human rights (Siddique and Uddin, 2016). The NBIM reaction was one of defiance (Oliver, 1991; Pache and Santos, 2010) and supports those concerned about SWF behaviour (Mehrpoya, 2015; Truman, 2010).

The literature suggests that combining logics can lead to organizational instability and field changes that are characterized by power struggles (Fligstein, 1987; Zilber, 2002). There was conflict between logics and institutions in the GPFG case (Reay and Hinings, 2010). The quote below illustrates this institutional conflict and struggle involved in linking the human rights and SWF fields and combining ethics and finance logics. The quote also indicates that accountability for human rights was imposed on NBIM (O’Dwyer and Boomsma, 2015).

\begin{abstract}
But there are of course important and heavy opposition to that they ${ }^{28}$ should take too much responsibility on the field of human rights and other social and environmental issues. And this was of course very controversial, and it took a long time for the political establishment to impose such an obligation on the Fund. And the development after shows that this is only one step in a struggle, which is still there, with the same type of opposing parties. OECD NCP in Norway, former member
\end{abstract}

The avoidance behaviour in response to the conflicting logics revealed a larger tension between the logics of the Bank and the Council which resulted in a number of significant changes in the system of accountability, designed to manage these tensions. The mandate of the OECD NCP was curtailed and

\footnotetext{
${ }^{27} \mathrm{PRI}=$ Principles for Responsible Investment, requires that ESG factors are considered in investment. The Global Compact and OECD Guidelines require that human rights are considered.

${ }^{28}$ They refers to NBIM (Bank of Norway).
} 
its leader was replaced (NRK, 2015; Forum interviewee). An important accountability mechanism was weakened in this clash between logics (Hoffman, 1999; OECD NCP interviewee). The Norwegian broadcaster NRK hinted that the change of OECD contact point leader in 2015 happened because the previous leader had made it clear that the lobbying by NBIM and the Ministry of Finance in the OECD undermined previous efforts by Norway and others in the human rights field (NRK, 2015). Others have suggested that the OECD NCP leader was removed because there were two other human rights complaints against NBIM in the OECD system and NBIM did not want this independent leader to handle these complaints (Forum interviewee, OECD Contact Point member). The new Contact Point leader in Norway dropped the cases against NBIM in 2015 which appears to reflect the relative power of the actors in the field (O'Sullivan and O'Dwyer, 2015). The NBIM vs OECD NCP case indicates that human rights posed a challenge to capitalism ( $\mathrm{Li}$ and McKernan, 2016). It also shows that capital (NBIM) may seek to avoid accountability for human rights.

However, the conflict beween NBIM and the OECD NCP, also led to further pressure from the NGO community and from parliament. The POSCO case resulted in NBIM being drawn into the investment and human rights field. NBIM subsequently held top level discussions with NGOs about human rights in 2015 (Forum interviewee). Demands from the Parliament, combined with the POSCO case, sparked work on a human rights expectation document by NBIM (Amnesty interviewee, OECD Contact Point interviewee). After initial conflict there was increasing engagement with actors in the field. In the end, POSCO and Daewoo were divested from the GPFG in 2015. However, the exclusion was recommended for serious environmental breaches (NBIM, 2015c). At times the GPFG struggled to implement the human rights part of its ethical policy. These developments indicate that:

\section{Human rights is a very complex field. Forum Interviewee}

In 2013 the Strategy Council of the GPFG published a report on the GPFG in which they proposed that the Council on Ethics should report to the Board of the Bank of Norway, rather than to the Ministry of Finance (Strategy Council, 2013). The Board of the Bank of Norway, which consists primarily of economists, would decide on the exclusions for the GPFG. This change was implemented from January 2015. The Strategy Council also suggested that the secretariat for the Council of Ethics should be integrated into the Bank of Norway (Strategy Council, 2013). In a more radical move, The Minister of Finance proposed to abolish the Council on Ethics (Halvorsen, 2014). The Norwegian Parliament rejected this proposal and the Council was retained and the secretariat remained independent from the NBIM (Innst. 200s 2013-2014). However, all the members of the Council were replaced from January 2015. The Bank has for the first time nominated the members of the Council on Ethics. The new mandate instructs the Council to co-operate with NBIM.

There has therefore been institutional conflict over how to organise the GPFG (Hoffman, 1999; O'Sullivan and O'Dwyer, 2015). Removing the decision on exclusions from the Ministry may be an attempt to remove the political "heat" from the Ministry on tough cases with international relations challenges. For example, the CE interviewee 2 mentioned that the new mandate in which the Board of the Bank of Norway decides on exclusion is an attempt to break the deadlock and stop the exclusions becoming "politicized". This may be an attempt to manage the institutional complexity of the GPFG (Greenwood et al., 2011).

A second possibility is that NBIM and the Ministry of Finance tried to capture the Council, which would have happened if the secretariat of the Council had been integrated into NBIM and the Council had been abolished (Halvorsen, 2014). The replacement of the members of the Council and the weakening of the OECD NCP accountability mechanism provide some evidence that this concern may be valid.

\section{Conclusions}


The established human rights paradigm is shifting. The scope of state responsibility for human rights is being extended to encompass their relationships with business, while corporations are also being asked to play a new role in respecting, protecting and remedying human rights ( $\mathrm{Li}$ and McKernan, 2016). The business and human rights agenda, therefore results in interplay between logics. Theoretically, this shift in the logics of the state and business results is complexity in established instititutional structures and their practices of accountability (Bovens, 1998). The Norwegian government's novel attempt to apply the UNGP's to the investment practices of its' SWF represents an important case that begins to shed light on the institutional responses when this human rights logic is introduced into established fields.

The Norwegian Government's response to the challenge of human rights had two key elements. First, to introduce an ethical policy and a new institutional accountability innovation -The Council on Ethicsto monitor firms in the GPFG. Second, for NBIM to engage firms on human rights. The Council introduced a new logic into the field and acted as an agent of change, innovation and disruption. The Council on Ethics recommended that some companies should be excluded from the GPFG due to human rights violations. We observed different responses to the recommendations for exclusion: human rights logic accepted; alignment leading to engagement; dissonance leading to rejecting the recommendations and, dissonance leading to avoidance of accountability and institutional conflict.

The case is characterized by greater complexity and multiplicity of outcomes than we anticipated. While other studies have identified examples of different responses to multiple institutional logics (Jay 2013; Pache and Santos, 2010; Reay and Hinings, 2009) we find these in a single case. We also identify possible reasons for these different responses.

In the Walmart and Zuari Agrochemicals cases the human rights logic was accepted by the Ministry of Finance and these firms were excluded from the GPFG. Secondly, the recommendations relating to children's rights generated innovation and engagement that led to less child labour in some farms connected to Monsanto in India (CE Interviewee 2 and 3). The sense within NBIM that something could be done about these violations appeared to be related to an alignment between the Council and how NBIM had begun to translate human rights in relation to childrens' rights. Dissonance leading to rejected recommendations seemed to result when the human rights violations were linked to countries with whom the Norwegian government wanted to maintain good relationships. A political logic allied with finance logic took precedence over the logic of the Council on Ethics. The negotiations of these divestments became politically sensitive and the recommendations were rejected.

However, this avoidance led to conflict. The GPFG case illustrates how incumbents defend their position against competing logics (Fligstein and McAdam, 2011). NBIM actively promoted its view in the OECD, seeking to limit investor responsibility for human rights (NRK, 2013; Curtis, 2014). This was an attempt to influence OECD based on NBIM's finance logic (O'Sullivan and O'Dwyer, 2015), in order to ensure dominance over competing logics (Reay and Hinings, 2010). Thus for NBIM it seemed accountability for human rights was imposed on it (O’Dwyer and Boomsma, 2015).

This case sits at the intersection of fields. As in the work of Reay and Hinings (2010) these logics co exist and we show how they play out in different ways depending on the relationship between logics and the particular situation. We show that when two logics were aligned, this had a decisive impact on outcome for the GPFG recommendations for exclusion. However, in Zilber's (2002) terminology we find a preponderance of "disequilibrium", leading to different outcomes depending on circumstances.

The Norwegian Government has gone further than most states in translating its responsibility for human rights into the investment practices of its SWF and we call on other governments and SWF's to learn 
from the GPFG case and implement human rights policies. The GPFG case shows that SWFs can be held accountable for human rights issues although it may be difficult. An actor giving voice to a human rights logic was essential in the GPFG case. Future research could investigate whether the new organisational arrangements for the GPFG results in a different pattern of exclusions.

\section{References}

Alm, K. (2013), "“The dark side of the moon': a theoretical framework of complicity applied to the Norwegian Government Pension Fund Global", Journal of Sustainable Finance \& Investment, Vol. 3 No. 3, pp.184-203.

Amland, B. (2011), "Norway feels sting of China's anger after Liu Xiabo Nobel Prize win", Huffingdonpost, 5.6.2011.

Battilana, J. and Dorado, S. (2010), "Building sustainable hybrid organizations: The case of commercial microfinance organizations", Academy of Management Journal, Vol. 53 No.6, pp.14191440.

Bay, I. (2002), Verdiløse penger? Oljefondet, veien mot etiske retningslinjer. FIVH Report 1/2002.

Binder, A. (2007), "For love and money: Organizations' creative responses to multiple environmental logics”, Theoretical Sociology, Vol. 36 No. 6, pp.547-571.

Bovens, M. (1998), The quest for responsibility : Accountability and citizenship in complex organisations. Cambridge, England; Cambridge University Press.

Bovens, M. (2010), "Two Concepts of Accountability: Accountability as a Virtue and as a Mechanism", West European Politics, Vol. 33 No.5, pp.946-967.

Braunstein, J. (2017), Sovereign wealth funds and ethical investment guidelines: the role of regime type, LSE Research Online, London.

Brinkmann, S. and Kvale, S. (2015), Interviews, Third edition, Sage, London.

Campbell, T. (2006), Rights: A Critical Introduction, Routledge, London.

Clark, G. and Hebb, T. (2004), "Pension fund corporate engagement, the fifth stage of capitalism", Relations Industrielles/Industrial Relations, Vol. 59 No. 1, pp.142-171.

Clegg, S. (2010), “The state, power and agency: Missing in action in institutional theory?", Journal of Management Inquiry, Vol. 19 No. 1, pp. 4-13.

Cooper, C., Coulson, A. and Taylor, P. (2011), "Accounting for human rights: Doxic health and safety practices - The accounting lesson from ICL", Critical Perspectives on Accounting, Vol.22 No. 8, pp.738-758.

Council on Ethics for the Government Pension Fund Global (2008), Annual Report, Oslo.

Council on Ethics for the Government Pension Fund Global (2011), Annual Report, Oslo.

Council on Ethics for the Government Pension Fund Global (2013), Annual Report, Oslo.

Council on Ethics for the Government Pension Fund Global (2014), Annual Report, Oslo.

Council on Ethics for the Government Pension Fund Global (2015), Annual Report, Oslo. 
Cragg, W., Arnold, D.G. and Muchlinski, P. (2012), "Human Rights \& Business", Business Ethics Quarterly, Vol. 22 No. 1 pp.1-7.

Crane, A. (2013), "Modern Slavery as a management practice: Exploring the conditions and capabilities for human exploitation", Academy of Management Review, Vol. 38 No. 1, pp.49-49.

Curtis, M. (2014), Moving backwards or forwards? Norway's approach to responsible investment, Forum, Oslo.

Dewenter, K., Han, X. and Malatesta, P. (2010), "Firm values and sovereign wealth fund investments", Journal of Financial Economics, Vol. 98 No. 2, pp.256-278.

Dimson, E., Karakas, O. and Li, X. (2015), “Active ownership”, Review of Financial Studies, Vol. 28 No. 12 , pp. 3225-3268.

Eisenhardt, K.M. (1989), "Building theories from case study research", Academy of Management Review, Vol. 14 No. 4, pp. 532-550.

Ezzamel, M., Robson, K., Stapleton, P. and McLean, M. (2007), "Discourse and institutional change: 'Giving accounts' and accountability", Management Accounting Research, Vol. 18 No. 2, pp. 150171.

Fligstein, N. (1987), “The intraorganizational power struggle: Rise of finance personnel to top leadership in large corporations, 1919-1979", American Sociological review, Vol. 52 No.1, pp.44-58.

Fligstein, N. and McAdam, D. (2011), "Toward a general theory of Strategic Action Fields", Sociological Theory, Vol. 29 No. 1, pp.1-26.

Friedland, R. and Alford, R. (1991), "Bringing society back in: Symbols, practices, and institutional contradictions", in The new institutionalism in organizational analysis, Powell, W. and Dimaggio, P. (Eds.), University of Chicago Press, Chicago, pp.232-263.

Gallhoefer, S., Haslam, J. and van der Walt, S. (2011), “Accountability and transparency in relation to human rights: A critical perspective reflecting upon accounting, corporate responsibility and ways forward in the context of globalisation", Critical Perspectives on Accounting, Vol.22 No. 8, pp.765780 .

Goodrick, E. and Salancik, G. (1996), "Organizational discretion in responding to institutional practices: Hospitals and cesarean births”, Administrative Science Quarterly, Vol. 41 No.1, pp.1-28.

Gregory, R., and Hicks, C. (1999), "Promoting Public Service Integrity: A Case for Responsible Accountability", Australian Journal of Public Administration, Vol. 58 No. 4, pp.3-15.

Greenwood, R., Oliver, C., Sahlin, K. and Suddaby, R. (Eds.) (2008), The Sage Handbook of Organizational Institutionalism, Sage Publications, London.

Greenwood, R., Raynard, M., Kodeih, F., Micelotta, E. and Lounsbury, M. (2011), "Institutional complexity and organizational responses", The Academy of Management Annals, Vol. 5 No. 1, pp.317-371.

Halvorsen, M. (2014), “Siv Jensen vil legge ned Etikkrådet”, DagensNceringsliv, 4.3.2014.

Hemstad, A. (2012), "Pensjonsfondet profitterer på barnearbeid”, Dagsavisen, inlegg 20.6.2012.

Hoffman, A. (1999), "Institutional evolution and change: Environmentalism and the US chemical industry", Academy of Management Journal, Vol. 42 No.2, pp.351-371. 
Human Rights Council (2011), Report of the special representative of the secretary general on the issue of human rights and transnational corporations and other business enterprises, John Ruggie. Final report for the UN Human Rights Council.

Innst. 200s (2013-2014), Innstilling fra finanskomiteen om forvaltningen av Statens pensjonsfond i 2013, Stortinget, Oslo.

Islam, M. and McPhail, K. (2011), "Regulating for corporate human rights abuses: The emergence of corporate reporting on the ILO's human rights standards within the global garment manufacturing and retail industry", Critical Perspectives on Accounting, Vol. 22 No. 8, pp.790-810.

Jay, J. (2013), "Navigating paradox as a mechanism of change and innovation in hybrid organizations", Academy of Management Journal, Vol. 56 No. 1, pp.137-159.

Johed, G and Catasus, B. (2015), "Institutional contradictions at and around the annual general meeting", Accounting, Auditing \& Accountability Journal, Vol.28 No.1, pp.102-127.

Kamuf, P. (2007), “Accounterability”, Textual Practice, Vol. 21 No. 2, pp.251-66.

Knill, A., Lee, B. and Mauck, N. (2012), "Bilateral political relations and sovereign wealth fund investment", Journal of Corporate Finance, Vol. 18 No. 8, pp.108-123.

Kotter, J. and Lel, U. (2011), "Friends or foes? Target selection decision of sovereign wealth funds and their consequences", Journal of Financial Economics, Vol. 101 No. 2, pp.360-381.

Kraatz, M. and Block, E. (2008), "Organizational implications of institutional pluralism”, in Greenwood, R., Oliver, C., Sahlin K. and R. Suddaby (Eds.), The Sage Handbook of Organizational institutionalism, Thousand Oakes, CA, pp.243-275.

Kreander, N., McPhail, K. and Beattie, V. (2015), "Charity ethical investments in Norway and the UK: A comparative institutional analysis including the impact of a sovereign wealth fund", Accounting, Auditing \& Accountability Journal, Vol. 28 No. 4 pp.581-617.

Kvam, A. (2008), “Why are children's rights an issue for investors?" Chronicle from 16.5.2008 available from www.norges-bank.no.

Li, Y. and McKernan, J. (2016),"Human rights, accounting, and the dialectic of equality and inequality", Accounting, Auditing \& Accountability Journal, Vol. 29 No. 4, pp.568 - 593.

Lounsbury, M. (2008), "Institutional rationality and practice variation: New directions in the institutional analysis of practice", Accounting, Organizations \& Society, Vol. 33 Nos. 4/5, pp.349361.

Lovvedtak 44 (2012-1013) accessed at www.stortinget.no/globalassets/pdf/vedtak-201213-044.pdf in 22.6.2016.

Lukka, K. (2014), "Exploring the possibilities for causal explanation in interpretive research", Accounting, Organizations \& Society, Vol. 39 No.7, pp.559-566.

MacDonald, K. (2011),"Re-thinking 'spheres of responsibility': business responsibility for indirect harm”, Journal of Business Ethics, Vol. 99 No 4, pp.549-563.

Marquis, C. and Lounsbury, M. (2007), "Vive la resistance: Competing logics and the consolidation of U.S. community banking", Academy of Management Journal, Vol. 50, pp.799-820.

McCorquodale, R. and Simons, P. (2007), "Responsibility beyond borders: State responsibility for extra territorial violations by corporations of international human rights law", Modern Law Review, Vol. 70 No. 4, pp.598-625. 
McKernan, J.F. (2012), “Accountability as aporia, testimony, and gift.” Critical Perspectives on Accounting, Vol. 23 No.3, pp.258-78.

McKernan, J.F. and McPhail, K. (2012), “Accountability and accounterability”, Critical Perspectives on Accounting, Vol. 23 No. 3, pp. 177-182.

McPhail, K. and Adams, C. (2016), "Corporate respect for human rights: meaning, scope, and the shifting order of discourse", Accounting, Auditing \& Accountability Journal, Vol. 29 No. 4, pp.650 678.

McPhail, K., MacDonald, K. and Ferguson, J. (2016), "Should the international accounting standards board have responsibility for human rights?", Accounting, Auditing \& Accountability Journal, Vol. 29 No. 4, pp.594-616.

McPherson, C. and Sauder, M. (2013), "Logics in action: Managing institutional complexity at a drug court”, Administrative Science Quarterly, Vol. 58 No. 2, pp.162-196.

Mehrpoya, A. (2015), "Instituting a transnational accountability regime: The case of Sovereign Wealth Funds and "GAPP"', Accounting, Organizations \& Society, Vol. 44 July, pp.15-36.

Meld.St.10 (2014-2015), Muligheter for alle - menneskerettighetene som mål og middel i utenrikes og utviklingspolitikken. Oslo.

Meld.St.21 (2014-2015), Forvaltningen av Statens Pensjonsfond i 2014., Oslo.

Mestad, O. (2011), “Attribution of responsibility to listed companies", in Nystuen, G. Follesdal, A. and Mestad, O. (Eds), Human rights, Corporate complicity and Disinvestment, Cambridge University Press, Cambridge, pp.79-106.

Meyer, J. and Rowan, B. (1977), "Institutionalized organizations: formal structure as myth and ceremony, American Journal of Sociology, Vol. 103 No.2, pp.340-363.

Meyer, J., Scott, W. and Strang, D. (1987), "Centralization, fragmentation and school district complexity”, Administrative Science Quarterly, Vol. 32 No.2, pp. 186-201.

Midttun, A., Gjølberg, M., Kourula, A., Sweet, S. and Vallentin, S. (2013), "Public policies for corporate social responsibility in advanced welfare states", in Midtun, A. (Ed.), CSR and Beyond, CappelenDamm, Oslo, pp. 261-286.

Ministry of Foreign Affairs (2015), Business and Human Rights, National action plan for the implementation of the UN Guiding Principles, Oslo.

Muchlinski, P. (2012), "Implementing the New UN Corporate Human Rights Framework: Implications for Corporate Law, Governance and Regulation”, Business Ethics Quarterly, Vol. 22 No.1, pp.145-177.

NBIM (2008), NBIM Investor expectations on children's rights, available online at www.nbim.no

NBIM (2010), Sector Compliance Report, Oslo. Available online at www.nbim.no

NBIM (2013), Annual Report, Oslo.

NBIM (2013b), Letter to Rainforest Foundation, dated 17.12.2013.

NBIM (2014), Management of the Government Pension Fund Global, Speech in Stortinget by Yngve Slyngstad, CEO of NBIM, published 25.4.2014.

NBIM (2014b), 2014 Responsible investment, Oslo. 
NBIM (2015), Annual Report, Oslo.

NBIM (2015b), Responsible investment 2015, Oslo.

NBIM (2015c), Decision on exclusion of companies from the Government Pension Fund Global, http://www.nbim.no/en/transparency/news-list/2015/decision-on-exclusion-of-companies-from-thegovernment-pension-fund-global/ accessed 24.8.2015 and 30.9.2015.

NBIM (2015d), Children's Rights, expectations towards companies, NBIM, Oslo.

NBIM (2016), Human Rights, expectations towards companies, NBIM, Oslo.

NBIM (2016b), Annual Report, Oslo.

Norwegian NCP for the OECD Guidelines (2013), Final Statement on complaint from Lok Shakti Abhiyan, Korean transnational corporations watch, Fair green global alliance and Forum for the environment and development vs. Posco (South Korea), ABP/APG (Netherlands) and NBIM (Norway).

NOU (2003:22), On the ethical guidelines of the government pension fund, report from the Graver Committee, Norwegian Government Green Paper, Oslo.

NRK (2013), Oljefondet ber OECD om å slippe etikkregler, 5.7.2013. available at www.NRK.no, accessed 1.6.2016 and 16.12.2016.

NRK (2015), dagsnytt atten 20.2.2015.https://tv.nrk.no/serie/dagsnytt-atten-tv/NNFA56022015/20-022015\#t=30m56s accessed 13.8.2015 and 15.9.2015.

Nystuen, G. (2011), "Disinvestment on the basis of corporate contribution to human rights violations: the case of the Norwegian Government Pension Fund", in Nystuen, G. Follesdal, A. and Mestad, O. (Eds), "Human rights, Corporate complicity and Disinvestment", Cambridge University Press, Cambridge, pp.16-43.

O’Dwyer, B. and Boomsma, R. (2015), “The co-construction of NGO accountability”, Accounting, Auditing \& Accountability Journal, Vol. 28 No. 1, pp.36 - 68.

OECD (2011), OECD Guidelines for multinational enterprises, OECD Publishing, Paris.

OECD (2014), Global Forum on responsible business conduct, Scope and application of business relationships in the financial sector under the OECD Guidelines for multinational enterprises, 26-27 June 2014, OECD Paris.

Oliver, C. (1991), "Strategic responses to institutional processes", Academy of Management Review, Vol. 16 No.1, pp.145-179.

O’Mahony, S. and Bechky, B. (2008), "Boundary organizations: Enabling collaboration among unexpected allies", Administrative Science Quarterly, Vol. 53 September, pp.422-459.

O'Sullivan, N. and O'Dwyer, B. (2015), “The structuration of issue based fields: Social Accountability, social movements and the Equator Principles issue-based field", Accounting, Organizations \& Society, Vol. 43 May, pp. 33-55.

Pache, A.C. and Santos, F. (2010), "When worlds collide: The internal dynamics of organizational responses to conflicting Institutional demands", Academy of Management Review, Vol. 35 No. 3, pp.455-476.

Pache, A.C. and Santos, F. (2013), "Inside the hybrid organizations: selective coupling as a response to competing logics", Academy of Management Journal, Vol. 56 No.4, pp.972-1001. 
Parker, L.D. and Northcott, D. (2016), "Qualitative generalising in accounting research: concepts and strategies", Accounting, Auditing \& Accountability Journal, Vol. 29 No. 6, pp.1100-1131.

Patton, M. (2002), Qualitative Reaearch \& Evaluation Methods, Sage Publications, London.

Rainforest Foundation (2012), Beauty and the Beast, Norway's investment in rainforest protection and rainforest destruction; report with Friends of the Earth Norway, Oslo.

Reay, T. and Hinings, R. (2010), "Managing the rivalry of competing institutional logics", Organization Studies, Vol. 30 No. 6, pp.629-652.

Reiche, D. (2010), "Sovereign wealth funds as a new instrument of climate protection policy? A case study of Norway as a pioneer of ethical guidelines for investment policy", Energy, Vol. 35 No. 9, pp.3569-3577.

Scott, R. (2008), “Approaching adulthood: the maturing of institutional theory", Theory and Society, Vol. 37 No. 5, pp. 427-442.

Seppälä, N. (2009), "Business and the international human rights regime: a comparison of UN initiatives", Journal of Business Ethics, Vol. 87 Supplement 2, pp. 401-417.

Siddique, J. and Uddin, S. (2016), "Human rights disasters, corporate accountability and the state: Lessons learned from Rana Plaza", Accounting, Auditing \& Accountability Journal, Vol. 29 No. 4, pp.679- 704 .

Sikka, P. (2011), "Accounting for human rights: the challenge of globalization and foreign investment agreements", Critical Perspectives on Accounting, Vol. 22 No. 8, pp.811-827.

Sinkovics, N., Hoque, S. and Sinkovics, R. (2016), "Rana Plaza collapse aftermath: are CSR compliance and auditing pressures effective", Accounting, Auditing \& Accountability Journal, Vol. 29 No. 4, pp. 617-649.

Skreddarberget, A. (2015), Usannsynlig rik, historien om Norge og Oljefondet, Skagge Forlag, Oslo.

Souitaris, V., Zerbinati, S. and Liu, G. (2012), "Which iron cage? Endo- and Exoisomorphism in corporate venture capital programs", Academy of Management Journal, Vol. 55 No. 2, pp. 477-505.

Stark, D. (2009), The sense of dissonance: Accounts of worth in economic life, Princeton University Press, Princeton.

St.Meld.nr.10 (2009), Næringslivets samfunnsansvar i en global økonomi, Det Kongelige Utenrikesdepartementet, Oslo.

Stohl, M. and Stohl, C. (2010), "Human rights and corporate social responsibility, Parallell processes and global opportunities for states, corporations and NGOs", Sustainability Accounting, Management and Policy Journal, Vol. 1 No. 1, pp. 51-65.

Strategy Council (2013), Responsible Investment and the Norwegian Government Pension Fund Global, Main report, available from www.regjeringen.no accessed 12.6.2014.

Suchman, M. (1995), "Managing legitimacy: Strategic and institutional approaches", Academy of Management Review, Vol. 20 No. 3, pp. 571-610.

Suddaby, R. (2010), “Challenges for institutional theory”, Journal of Management Inquiry, Vol. 19 No.1, pp.14-20.

Takla, E. (2011), “Nekter å kaste ut kinesisk gigant”, DagensNceringsliv 6.11. 
Thornton, P. and Ocasio, W. (1999), "Institutional logics and the historical contingency of power in organizations. Executive succession in the higher education publishing, 1958-1990", American Journal of Sociology, Vol. 105 No.3, pp.801-843.

Truman, E. (2010), Sovereign wealth funds, threat or salvation? Peterson Institute for International Economics, Washington DC.

Uche, C., Adegbite E. and Jones, M. (2016), "Institutional shareholders activism in Nigeria: An accountability perspective", Accounting Forum, Vol. 40, pp,78-88.

UNICEF (2012), «Sustainability reporting on children's rights», UNICEF working paper, published in December 2012.

Wettstein, F. (2012), "CSR and the debate on business and human rights: Bridging the great divide", Business Ethics Quarterly, Vol. 22 No. 4, pp.739-770.

Zilber, T.B. (2002), "Institutionalisation as an interplay between actions, meanings and actors: The case of a rape crisis center in Israel", Academy of Management Journal, Vol. 45 No. 1, pp. 234-254.

www.swfinstitute.org (accessed 12.11.2014, 25.7.2015, 1.12.2016 and 28.5.2018). 
Table 1 Interviewees

\begin{tabular}{|l|l|l|l|}
\hline Organization & Position of Interviewee & $\begin{array}{l}\text { Location of } \\
\text { interview }\end{array}$ & Time \\
\hline Council on Ethics & Member, CE Interviewee 1 & Oslo & May 2014 \\
\hline Council on Ethics & Member of the Secretariat & Oslo & August 2014 \\
\hline Ministry of Finance & $\begin{array}{l}\text { Former Staff member at Asset } \\
\text { Management, interviewee 1 }\end{array}$ & Oslo & September 2014 \\
\hline OECD Contact Point (Norway) & $\begin{array}{l}\text { Member and an Advisor to the } \\
\text { secretariat }\end{array}$ & Oslo & $\begin{array}{l}\text { September 2014, } \\
\text { August 2015 }\end{array}$ \\
\hline Ministry of Finance (Norway) & Former advisor, interviewee 2 & Buxton & November 2014 \\
\hline NBIM & Former analyst, Interviewee 1 & Oslo & December 2014 \\
\hline Council on Ethics & $\begin{array}{l}\text { Former member, CE } \\
\text { Interviewee 2 }\end{array}$ & Tønsberg & January 2015 \\
\hline NBIM & $\begin{array}{l}\text { Former ESG staff member } \\
\text { Interviewee 2 }\end{array}$ & Stockholm & March 2015 \\
\hline Forum & CSR Co-ordinator & Oslo & August 2015 \\
\hline OECD Contact Point (Norway) & Former member & Oslo & August 2015 \\
\hline Amnesty & Political advisor & Oslo & September 2015 \\
\hline Rainforest Foundation & Campaign Director & Oslo & November 2015 \\
\hline Council on Ethics & Member, CE interviewee 3 & Oslo & November 2015 \\
\hline GPFG Strategy Council & Member, Strategy Council & Oslo & May 2016 \\
\hline
\end{tabular}

\footnotetext{
${ }^{1}$ In some cases the full position is not disclosed for confidentiality reasons.
} 
Table 2 Companies recommended for exclusion due to human rights violations

\begin{tabular}{|c|c|c|c|}
\hline Company & Human Right & $\begin{array}{l}\text { Location of } \\
\text { violation }\end{array}$ & Result \\
\hline $\begin{array}{l}\text { Walmart Inc (USA) } \\
\text { Wal-Mart de Mexico }\end{array}$ & Labour rights & $\begin{array}{l}\text { USA, other } \\
\text { countries }\end{array}$ & Excluded in 2005. \\
\hline $\begin{array}{l}\text { Monsanto } \\
\text { (USA) }\end{array}$ & Child labour & India & $\begin{array}{l}\text { Recommendation in } 2006 \text { was } \\
\text { exclusion. Exclusion reversed in } 2008 . \\
\text { In GPFG portfolio. }\end{array}$ \\
\hline $\begin{array}{l}\text { Daewoo International } \\
\text { (South Korea) }\end{array}$ & $\begin{array}{l}\text { Original peoples rights, } \\
\text { forced labour, rape, other }\end{array}$ & Myanmar & $\begin{array}{l}\text { Exclusion recommended in } 2011 . \\
\text { Recommendation withdrawn in } 2013 . \\
\text { Divested in } 2015 \text { for environmental } \\
\text { reasons. }\end{array}$ \\
\hline $\begin{array}{l}\text { Gail India } \\
\text { (India) }\end{array}$ & Original peoples rights & Myanmar & $\begin{array}{l}\text { Exclusion recommended in } 2011 . \\
\text { Recommendation withdrawn in } 2013 . \\
\text { In GPFG portfolio. }\end{array}$ \\
\hline $\begin{array}{l}\text { Korea Gas } \\
\text { (South Korea) }\end{array}$ & Original peoples rights & Myanmar & $\begin{array}{l}\text { Exclusion recommended in } 2011 . \\
\text { Recommendation withdrawn in } 2013 . \\
\text { In portfolio. }\end{array}$ \\
\hline $\begin{array}{l}\text { ONGC } \\
\text { (India) }\end{array}$ & Original peoples rights & Myanmar & $\begin{array}{l}\text { Exclusion recommended in } 2011 . \\
\text { Recommendation withdrawn in } 2013 . \\
\text { Divested in } \mathbf{2 0 1 9} \text { for oil exploration. }\end{array}$ \\
\hline $\begin{array}{l}\text { POSCO } \\
\text { (South Korea) }\end{array}$ & Original peoples rights & Myanmar & $\begin{array}{l}\text { Exclusion recommended in } 2012 . \\
\text { Recommendation withdrawn in } 2013 . \\
\text { Divested in } \mathbf{2 0 1 5} \text { for environmental } \\
\text { reasons. }\end{array}$ \\
\hline $\begin{array}{l}\text { Vedanta Resources } \\
\text { (UK/India) }\end{array}$ & $\begin{array}{l}\text { Original peoples rights } \\
\text { Forced relocation }\end{array}$ & India & Excluded in 2007. \\
\hline $\begin{array}{l}\text { Sesa Sterlite (India) } \\
\text { Daughter company to } \\
\text { Vedanta }\end{array}$ & & India & Excluded in 2007. \\
\hline $\begin{array}{l}\text { PetroChina } \\
\text { (China) }\end{array}$ & Original peoples rights & Myanmar & $\begin{array}{l}\text { Exclusion recommended in } 2010, \\
\text { Ministry refused in 2011. In portfolio. }\end{array}$ \\
\hline $\begin{array}{l}\text { Zuari Agrochemicals } \\
\text { (India) }\end{array}$ & Childrens' rights & India & Excluded in 2013. \\
\hline $\begin{array}{l}\text { Repsol (Spain) and } \\
\text { Reliance Industries } \\
\text { (India) }\end{array}$ & Original peoples rights & Peru & $\begin{array}{l}\text { Recommended for exclusion in } 2010 . \\
\text { Recommendation withdrawn in } 2014 . \\
\text { Companies in Portfolio. }\end{array}$ \\
\hline $\begin{array}{l}\text { Tahoe Resources } \\
\text { (USA) }\end{array}$ & Original peoples rights & Guatemala & $\begin{array}{l}\text { Recommended for exclusion in } 2014 . \\
\text { Divested in } 2014\end{array}$ \\
\hline
\end{tabular}


Table 3 NBIM holdings in companies recommended for exclusion

\begin{tabular}{|l|c|c|c|c|}
\hline Company & $\mathbf{2 0 1 0}$ & $\begin{array}{l}\text { Exclusion } \\
\text { recommended }\end{array}$ & $\mathbf{2 0 1 4}$ & $\begin{array}{c}\text { Expected Value } \\
\mathbf{2 0 1 4}\end{array}$ \\
\hline $\begin{array}{l}\text { Daewoo } \\
\text { International }\end{array}$ & 7,7 & 2011 & 67,7 & 11,3 \\
\hline (ownership share) & $(0,04 \%)$ & & $(0,28 \%)$ & \\
\hline Gail India & 500,2 & 2011 & 499,1 & $(0,74 \%)$ \\
\hline (ownership share) & $(0,59 \%)$ & & 121,4 & 8,1 \\
\hline Korea Gas & 5,5 & 2011 & $(0,39 \%)$ 口 & \\
\hline (ownership share) & $(0,03 \%)$ & & 808 & $(0,23 \%)$ \\
\hline ONGC & 263 & 2011 & 2583,5 & 875,7 \\
\hline (ownership share) & $(0,07 \%)$ & & $(0,17 \%)$ & \\
\hline PetroChina & 597,6 & 2010 & 1485,3 & \\
\hline (ownership share) & $(0,04 \%)$ & & $(0,91 \%)$ & 1591,5 \\
\hline POSCO & 1085,3 & 2012 & & \\
\hline (ownership share) & $(0,5 \%)$ & & & \\
\hline
\end{tabular}

Table 3 gives GPFG holdings in millions of NOK in December 2010 and 2014 in companies recommended for exclusion for human rights violations. Beneath this figure is how much the GPFG owns of the company as a percentage of shares. The value of the GPFG in 2010 was 3077 billion NOK and this increased to 6431 billion in 2014. The expected value is calculated using the growth rate of the equity portfolio.

Source: www.nbim.no 
Figure 1 Key actors related to the GPFG in 2014

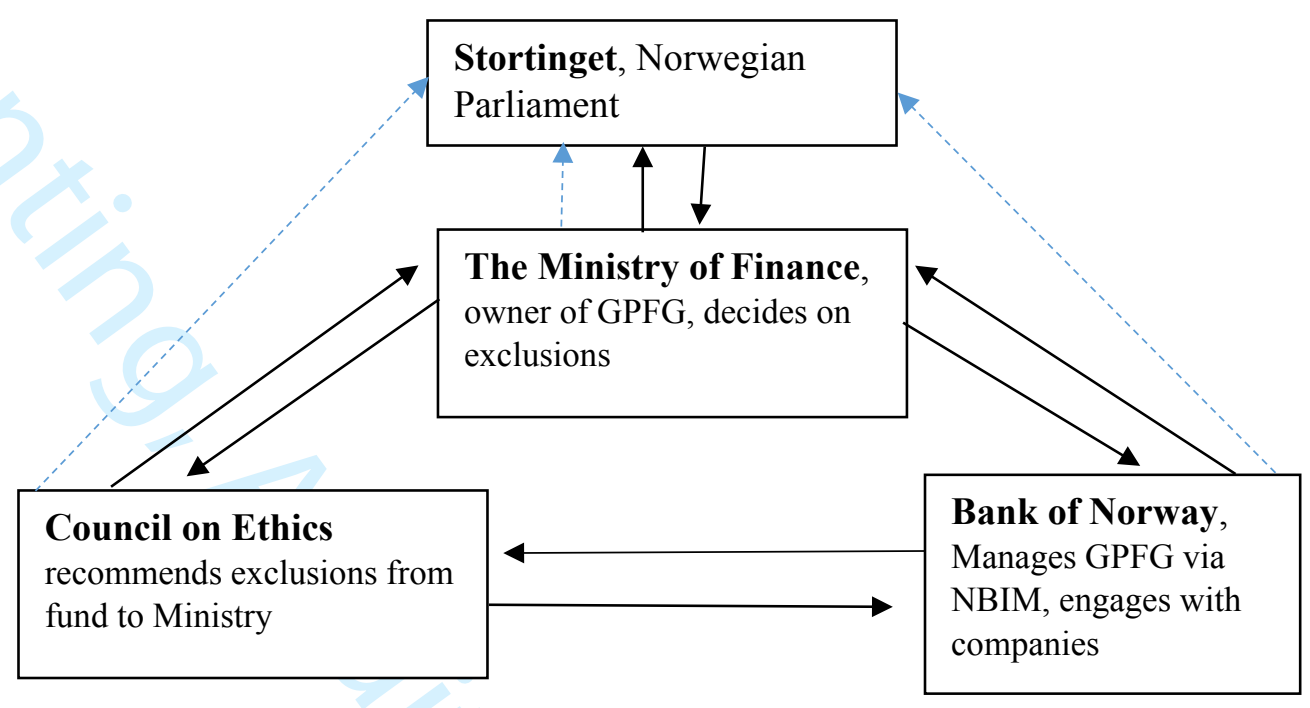




\section{Appendix 1 Timeline of Government Pension Fund: Global and Human Rights}

1990 Parliament approved law about the Oilfund

1996 First money into the GPFG

1998 NBIM established and first investments in company shares

2003 Government Green Paper (NOU 2003:22) lays foundations for the ethics of the GPFG

2004 Ethical investment policy and Council on Ethics established (human rights included)

2008 NBIM launches expectation document on children's rights

2009 Consultation, evaluation and revision of GPFG Ethical investment policy

2011 UN Guiding Principles on Human Rights launched

2013 Strategy Council of the GPFG suggests changes to responsible investment strategy

2014 Battle of the Council on Ethics (Minister of Finance wants to abolish the Council)

2015 Board of the Bank of Norway decides on exclusions

New Council on Ethics appointed, led by an investor

NBIM updates expectation document on children's rights

Norway launches National strategy for Business and Human Rights and a National Action Plan for implementing the UNGP

2016 Human Rights expectation document launched by NBIM 